\title{
Biosphere Compatibility as a Principle of Sustainable Urban Development
}

\author{
Zinaida Ivanova ${ }^{1,{ }^{*}}$, Olga Yudenkova ${ }^{1}$, and Jurga Naimaviciene $^{2}$ \\ ${ }^{1}$ Moscow State University of Civil Engineering, 129337 Yaroslavskoye sh. 26, Moscow, Russia \\ ${ }^{2}$ Vilnius Gediminas Technical University, 10223 Sauletekio al. 11, Vilnius, Lithuania
}

\begin{abstract}
The article covers safety and environmental issues, as well as the sustainable interaction between man and nature in the context of present-day cities. An important task, according to the authors, is the study of scientific approaches and practical achievements in this field, and then the detection of the most urgent critical issues. The coauthors provide an overview of numerous research projects on the treatment of nature, the anthropogenic load, the biosphere as a geological body, the noosphere, and ratios characterizing the condition of the biosphere. The coauthors believe that ecological management, aimed to reverse the treatment of nature, must be integrative. New legislation, effective control of its execution, new disciplines to be introduced at the level of secondary, vocational, and higher education, development of ecological schools of thought and advanced green standards and materials applicable to any construction operations may comprise an effective solution. The authors offer their vision of the challenges and outline the primary steps, including immediate implementation of urban planning solutions to be developed in accordance with the biosphere compatibility principles, with calculations of humanitarian balances of the bio-technosphere. The coauthors also consider the innovative approaches to the use of eco-friendly materials in construction projects.
\end{abstract}

\section{Introduction}

Safe and sustainable environment is the objective to be attained in the $21^{\text {st }}$ century. Environmental problems are comprehensive; they arise from the improper treatment of nature [1]. These problems are especially grave in the areas exposed to strong anthropogenic impacts, including hazardous emissions, air pollution, soil and water contaminations, extinction of forests and parks. These problems cause social diseases, including hypodynamia, stresses, and irregular behaviour patterns that produce negative effects on human health (alcoholism, desolation, drug addiction, criminality, smoking, etc.) Russian cities (that accommodate about $74 \%$ of the country's population) are unsafe for their residents. According to the Global Liveable Cities Index (GLCI), published by the World Review of Science, Technology and Sustainable Development, Moscow has taken the $64^{\text {th }}$ position in the rating of good-for-living cities. The Global Liveable Cities Index

* Corresponding author: ivanovazi@mail.ru 
assesses urban culture, social environment, economy, ecological safety, and competitive strengths [2].

Ecological problems are particularly pressing in Siberia and the Arctic Region (Russia); these areas have a changeful landscape, and they are highly sensitive to any external influence. For example, the value of the scattering property of the atmosphere in Eastern Siberia is half the value of the atmosphere of the European territory of the Russian Federation. However, this factor was disregarded when industrial enterprises, cities and villages were constructed there. This is the reason why the majority of Siberian cities and all industrial areas of Siberia demonstrate excessive air and water pollution.

The Arctic Region is contaminated by oil, heavy metals, and radioactive substances. This is a unique territory, rich for islands, seas and archipelagos; it is frail and easy to exhaust. The consumption of it biological resources should be performed under strict control, with account for the regeneration patterns tailored to local organisms.

This is the reason why ecologists insist on (1) the sustainable development of Northern areas, (2) the control over any activities in offshore zones and in the areas of mineral/fuel resources recovery, (3) the prevention of any destruction of the natural environment exposed to anthropogenic impacts.

We are sure that man produced the initial negative impact on nature in the ancient times rather than in the 20ieth century. The culture of humans develops around the human ability to get accustomed to nature, on the one hand, and to change it, on the other hand. Nature has been exposed to numerous adverse impacts in the course of the human history, although the intensity of impacts was different in different centuries. Back in the ancient times, humans burnt grass away to get more space for their cows and sheep, and therefore, fires spread over extensive areas of forests and steppes. "The ecological effect of these fires caused succession of plants: moist forests gave way to shrubs and savannas, soil composition and structure changed, and the same about the climate" [3].

L.N. Gumilev, a Russian ethnologist and geographer, wrote that "the predatory treatment of nature by humans may occur in any social system; therefore, it can hardly be considered as a consequence of the social progress" [4]. However, the events of the 20th century cannot compare to the environmental changes that occurred in the course of dozens of millennia. Back then, the biosphere had a chance to restore, to generate new landscapes, to create and to multiply its flora and fauna.

\section{Developments}

Many scholars, who study the ecological and physical peculiarities of Earth and nature, believe that, unless urgent measures are taken now, environmental changes may turn irreversible. Researchers have done their best to surmount the crisis and to draw the public attention to sustainable development; however their efforts cannot convert into the public need, or into the collective consciousness of governments, municipal authorities, business communities, and urban residents. When setting limits to growth, D. Meadows, J. Randers, and D. Meadows warned: "Unfortunately, the environmental load imposed by humans keeps growing, despite any technological developments and efforts invested by public organizations. The situation turns more serious, as the humankind has already stepped beyond the limits into the instable domain. Nonetheless, the understanding of this problem is desperately poor worldwide. There is a need to reconsider personal and public values to reduce the impact produced on the environment and to roll back to the acceptable level, and a lot of time is needed to win the support from the politicians in this respect" [5].

The essence of sustainable urban development means the repletion of human needs without any damage to future generations. Russian scholar Vladimir Vernadsky generated this concept and developed the notion of the biosphere as a geological body, whose 
structure and functions were based on the features of Earth, Cosmos, living creatures, populations, species, or the living matter. He believed that any human activity was a natural step towards the development of the biosphere. “... in the recent centuries, the human society produced all the more pronounced influence on the environment encompassing the living matter. In the biosphere, or in the upper shell of our planet, this society turned into the sole agent of its kind whose strength grew as long as the time progressed"[6]. Vladimir Vernadsky employed the term "noosphere", initially introduced by Armand Marie Leroi, a French mathematician, to define the area of interaction between nature and society, or the future condition of the biosphere transformed by the collective mind and effort of the humans. Vladimir Vernadsky believed that the treatment of nature and its resources would turn more reasonable in the future and that it would be aimed at its preservation, renewal, and improvement.

Whenever we attempt to develop Vernadsky's research ideas, we realize that the noosphere is created by the man. The noosphere represents the future condition of the biosphere and the outcome of the scientific thought, capable of reengineering the biosphere into the noosphere as the realm of reason. Is it possible?

In his works, Vernadsky enlisted the conditions that set the stage for the positive development of the noosphere, with the conscientious attitude towards the consumption of natural resources being the top priority. He wrote: "The problems of food and production must be reconsidered. As a result, the upheaval of social principles, which control the public opinion, will follow" [6]. The main principles, developed by Vernadsky, include (1) the equality of all human races and confessions; (2) a higher impact produced by the grassroots onto interior and international policies, (3) the freedom of scientific thought from any pressure produced by religious, philosophical, or political constructs, and setting the stage for free scientific research in public and social systems; (4) the growth of the public welfare. As for the biosphere, Vernadsky developed a sensible transformation methodology for the Earth's nature to satisfy all material, aesthetic, and spiritual needs of the evergrowing population.

Russian scientist Vyacheslav Ilyichev, member of the Russian Academy of Architecture and Construction Sciences, is developing the general ideas, initially proposed by Vernadsky, into specific actions, aimed at the improvement of the biosphere's development pattern. He authors a set of theoretical principles underlying the transformation of cities into biosphere compatible ones capable of developing humans. He also offers practical, technological and economic instruments to implement the transformation in question [7].

Ilyichev's major contribution is a pattern of calculations of humanitarian balances of the Bio-technosphere, designated for the identification of ratios between (f) the biosphere's life potential, population numbers, and the number of areas, where human needs are satisfied; (b) the needs for the biosphere's resources expressed by the humans and the technosphere, as well as the ability of the regions to satisfy them [8]. This collection of methods is a novel branch of urban research; it is in compliance with the concept of sustainable urban development. The main objectives of the research team, headed by Vladimir Ilyichev, are to assess the deterioration of the biosphere in different regions, to identify the extent of the biosphere compatibility in urban areas, and to calculate the ratios. The natural environment has already been assessed in several Russian cities, and the ratios of the bio-technosphere have been calculated there (the ratios have taken account of airflows, impacts produced by the vegetation, etc.). Moreover, Ilyichev has offered efficient power-saving technologies that transform urban pathologies into development resources. He also transforms architectural design projects by introducing natural ventilation and lighting elements.

The implementation of the V. Ilyichev's concept has been initiated. For example, the humanitarian balances of the bio-technosphere (including costs, expenses, maintenance, and restoration) were calculated in the course of development of the project for the redesign 
of the embankments of the Oka and Orlik rivers in Orel. The Ilyichev's team offered the numerical implementation for the methodology of calculation of the bio-technosphere in cities and villages and identified the feasibility values for specific urban functions. The calculations were made on the basis of the following two factors: the biosphere's resources available and the needs of residents. Moreover, the project developers took account of the town-planning regulations applicable to leisure zones located in the first and second belts of water protection areas. The methodologies at the disposal of the Ilyichev's team provide for the calculation of the humanitarian balances with account for the preservation of the atmosphere and development of comfortable urban environment safe for its residents. The average feasibility ratio for the functions of a biosphere compatible city reached $79.2 \%$ in terms of the project on the restructuring of the embankments of the Oka and Orlik rivers. [5, p. 98]

Present-day environmental research projects are developed with regard to the social constituents of biosphere compatible cities. Russian researchers, including V.A. Ilyichev, K.K. Kolin, A.D. Ursul, I.K. Liseev, study the social issues of urban planning [10-13]. Social and humanitarian problems, covered in the urban development doctrine, developed by the Ilyichev's team of researchers, are analyzed in numerous research articles [14-15].

The co-authors of the paper are involved in the research into socio-humanitarian features of biosphere compatible cities; however the co-authors admit that this problem does not have any technology-intensive solution. Therefore, humans need to change their mindset; the pattern of the human treatment of the biosphere needs improvements, and Earth should no longer be exploited. We must interact with Earth as if it were living matter. If we fail, no technology problems will be

solved even on paper. The coauthors also participate in the development of the fundamentals of ecological ethics; they think of advanced behavioral patterns originating from the basic ones typical for the archetypes of the collective unconscious, or ethnically mental and ethnically religious fundamentals of biosphere compatible villages, wide-scale migration, development of the positive ethnic climate in cities, and social aspects of the biosphere compatibility in architectural projects [16]. The coauthors and their colleagues solve problems of management competencies on the basis of the new regulations set by the Federal State Educational Standards in respect of the training of civil engineers, urban planners, and managers, who will be able to implement the principle of the biosphere compatibility in their work [17].

"The symbiosis with the biosphere is necessary and possible, if and when the man develops, if his philosophical, moral and ethical mindset focuses on the cooperation with the biosphere as a system that is superior to the human civilization," says V. Ilyichev [18] "... the formation of the post-industrial civilization shall involve not only a technological revolution, but also a spiritual reformation, criticism and reconsideration of several former basic values of the anthropogenic culture (its treatment of nature, its cult of power as the basis for transformation, its ideals of the consumer society based on the rising consumption of goods and energy, etc.)," concludes V.S. Stepin, a prominent philosopher and member of the Russian Academy of Sciences [19].

Researchers stand for the civilizational changeover; however this changeover is an extensive process that covers the life periods of several generations. What particular resources do we have at our disposal in order to transform the human mindset, to develop the need for a safe environment? For example, how strong is the need for the ecological housing, and how can this need be developed? The eco-sustainable architectural design and the green building philosophy represent the notions and concepts that are much spoken about, but so far they are relevant on paper, as all parties involved in the construction process - investors, architects, developers - fail to implement these concepts, although they realize the need to recognize the ecological requirements and to assure the natural comfort 
on construction sites and inside new buildings [20]. This state of affairs needs to be changed, but the psychological problem prevents any changes. "Any social changes, declared and adopted by the society, start working when they convert into a mental set that triggers and guides the individual behavior" [21]. For example, many Russian citizens cannot change their behavioral pattern when buying construction materials. Their price, rather than their ecological safety, is the purchase driver. The mission of the ecological management is to develop a conscious human need in safe construction and finishing materials.

Residents start making demands for ecological residential houses, although these demands are unconscious and weak [22]. According to A.D. Remizov, Chairman of the Board, Green Building Council, eco-sustainable architecture can only be boosted by the demand from the society, the business community, and state authorities. "... there is a need for a new mindset that does not oppose man to nature. A new attitude towards consumption must serve as a means for the implementation of new principles. Being a consumer, the man must take account of the concerns of other species and the planet as a whole: thus, the severe exploitation of Earth, the devastation of forests and wildlife habitats, the industrial and economic development, changing the climate on the planet, are inadmissible. And the man himself, being part of nature, needs a sustainable, healthy and society-oriented environment" [23].

According to A. Remizov, the mission of ecologically sustainable architecture and urban development is to develop and maintain:

- cultural values (originality of local areas, contextual and historic correlations, development of the sense of place);

- social values (social involvement, solidarity, good neighborliness, crime reduction, civil dignity development);

- economic values (rate of return, real estate cost growth, capital return);

- consumption values (job satisfaction, labour capacity improvement, health improvement, education availability, location satisfaction);

- environmental values (protection of species, health improvement, reduction of waste and $\mathrm{CO}_{2}$ emissions, life fullness) [24].

The ideas, formulated by A. Remizov, comply with the concept, developed by $\mathrm{Z}$. Gaevskaya and S. Mityagin, who believe that the capital construction management must be based on the economic capacity of the biosphere and on the interaction between natural and anthropogenic structures and processes [25].

The concepts proposed by the researchers, specializing in the study of the interaction between man and nature, are embodied in the effective legislative acts [26]. The provision of the Urban Planning Code of the Russian Federation that reads as: "Assurance of wellbalanced consideration of ecological, economic, social and other factors in the course of performance of urban planning activities" serves as a main principle underlying architectural design and construction [27]. Besides, according to the Federal Law on Environmental Protection, when buildings, houses, structures and other facilities are designed, account shall be taken of the norms of the admissible human load on the environment, measures shall be arranged for preventing and eliminating environmental pollution and also for disposing of the industrial and consumption waste; resource-saving, low-waste and other best existing technologies shall be employed in environmental protection, restoration of natural environment, rational use and reproduction of resources [28].

Not only new construction should be "green", but also reconstruction and restoration of buildings and structures and all the real estate as a whole. "Renovation of the built and human environment must be considered instead and the holistic approach used. From this perspective, decision-making problems of renovation often involve a complex decision 
making process in which multiple requirements and conditions have to be taken into consideration simultaneously» $[29,30]$. In the majority of the developed countries the amount of capital investments into housing hasn't greatly changed, but the structure of their use changed. The funds are devoted mainly not for new housing, but for renovation of the existing housing stock. The concept of the integrated analysis of built and human environment renovation developed by a Lithuanian researcher Prof. Arturas Kaklauskas from Vilnius Gediminas Technical University and his creative team allow controlling the whole lifecycle of buildings. The build-up environment is considered as a complicated constantly changing system, in which controlled and uncontrolled factors are operating and which depends on the definite number of variables on micro-, meso- and macrolevels. One of the most important factors is the exhaust of natural resources. "The construction activity should be organized in the way so that the negative impact on the environment and energy consumption would be minimal during the whole period of building existence (i.e. as of the moment of design, production of building materials, including recycling and recycled building materials and products, construction, operation, property management of buildings, and demolition). Towards this end, it is necessary to implement a system of actions" [31, 32]. Among them, there is the reduction of waste volume during building existence, increase of thermal insulation of buildings, hot water saving and heating, the use of renewable construction resources and energy.

\section{Conclusions}

On the basis of the above ideas, the coauthors propose several focus areas and urgent actions in the field of interaction between the man and the human society, on the one hand, and the biosphere, on the other hand.

\begin{tabular}{|c|c|c|c|}
\hline No & Focus Area & Goals and Objectives & Urgent Actions \\
\hline 1 & $\begin{array}{l}\text { Legislative recognition } \\
\text { of the values of nature. } \\
\text { Tight control over the } \\
\text { execution of laws. }\end{array}$ & $\begin{array}{l}\text { Human health and safety } \\
\text { protection of life. } \\
\text { Preservation of human } \\
\text { health and provision of } \\
\text { safety. Enforcement of } \\
\text { law and order for the sake } \\
\text { of ecological safety. }\end{array}$ & $\begin{array}{l}\text { 1. Legislative strengthening of the } \\
\text { humanitarian balance of bio- } \\
\text { technosphere in regions (or phased } \\
\text { transition). } \\
\text { 3. Development of an efficient system } \\
\text { of control over the execution of } \\
\text { legislation by the organizations of the } \\
\text { civil society. }\end{array}$ \\
\hline 2 & $\begin{array}{l}\text { Development of the } \\
\text { ecological culture and } \\
\text { ecological } \\
\text { enlightenment, methods } \\
\text { of ecological } \\
\text { upbringing and } \\
\text { education. }\end{array}$ & $\begin{array}{l}\text { Development of the } \\
\text { ecological conscience, } \\
\text { ecological ethics and } \\
\text { aesthetics, and deliberate } \\
\text { personal needs for the } \\
\text { harmonious coexistence } \\
\text { with the natural world, a } \\
\text { caring treatment of nature, } \\
\text { and proactive behavior } \\
\text { aimed at the attainment of } \\
\text { the above objectives. }\end{array}$ & $\begin{array}{l}\text { 1. Expansion of ecological modules } \\
\text { for programmes of general secondary, } \\
\text { vocational secondary and higher } \\
\text { levels of education. Continuity of the } \\
\text { ecological education. } \\
\text { 2. Development of integrated } \\
\text { interdisciplinary educational modules; } \\
\text { integrative education. } \\
\text { 3. Assurance of higher ecological } \\
\text { competencies of students majoring in } \\
\text { areas different from ecology. } \\
\text { 4. A stronger role of the social } \\
\text { disciplines, designated to develop the } \\
\text { new mindset. }\end{array}$ \\
\hline
\end{tabular}




\begin{tabular}{|c|c|c|c|}
\hline 3 & $\begin{array}{l}\text { Training of high quality } \\
\text { specialists in ecology. } \\
\text { Introduction of } \\
\text { obligatory positions of } \\
\text { environmental } \\
\text { specialists. }\end{array}$ & $\begin{array}{l}\text { Competent resolution of } \\
\text { environmental problems. } \\
\text { Ecological control over } \\
\text { any economic activities to } \\
\text { be performed by } \\
\text { enterprises or } \\
\text { organizations. }\end{array}$ & $\begin{array}{l}\text { 1. Introduction of a new speciality of } \\
\text { an environmental specialist. } \\
\text { 2. Development of a standard set of } \\
\text { responsibilities to be performed by } \\
\text { the future specialists. }\end{array}$ \\
\hline 4 & $\begin{array}{l}\text { Development of } \\
\text { environmental sciences, } \\
\text { environment friendly } \\
\text { technologies and } \\
\text { machinery. }\end{array}$ & $\begin{array}{l}\text { Identification of trends in } \\
\text { the development of the } \\
\text { biosphere and projection } \\
\text { of consequences of varied } \\
\text { economic solutions. } \\
\text { Development of } \\
\text { theoretical models for the } \\
\text { further development of } \\
\text { the biosphere. } \\
\text { Resolution of acute } \\
\text { environmental problems } \\
\text { through the employment } \\
\text { of advanced scientific } \\
\text { achievements. }\end{array}$ & $\begin{array}{l}\text { 1. Development of research schools } \\
\text { of the environmental thought. } \\
\text { 2. State support of research projects } \\
\text { contemplating the development of } \\
\text { innovative technologies. } \\
\text { 3. Getting young and talented } \\
\text { graduates involved in research } \\
\text { activities; the training and } \\
\text { maintenance of the high quality } \\
\text { human capital. } \\
\text { 4. Launching integrated research } \\
\text { projects on the problems of the } \\
\text { biosphere to be developed and } \\
\text { implemented by the teams of } \\
\text { researchers specializing in versatile } \\
\text { areas of knowledge. }\end{array}$ \\
\hline 5 & $\begin{array}{l}\text { Urban planning } \\
\text { solutions to be } \\
\text { developed in } \\
\text { furtherance of the } \\
\text { biosphere compatibility } \\
\text { principles, including the } \\
\text { green building } \\
\text { methodology and the } \\
\text { ecologically sustainable } \\
\text { architectural design. } \\
\text { Development of a } \\
\text { network of ecological } \\
\text { villages. }\end{array}$ & $\begin{array}{l}\text { A symbiotic coexistence } \\
\text { of the city, the biosphere } \\
\text { and human. }\end{array}$ & $\begin{array}{l}\text { 1. Integrated design projects are to be } \\
\text { developed by teams of versatile } \\
\text { specialists in architectural and } \\
\text { structural design. } \\
\text { 2. Scientific knowledge advancement } \\
\text { in the fields of advanced construction } \\
\text { materials and technologies, resources } \\
\text { recycling, alternative energy sources, } \\
\text { active and passive methods of } \\
\text { resources saving. }\end{array}$ \\
\hline
\end{tabular}

Each of the actions above must be treated as the one of paramount importance and included into the list of Russia's strategic priorities. Initial actions should consist in the development of the state policy on the interaction between the society and the biosphere, as well as in the development of specific actions aimed at the implementation of this policy, provision of the state funding, and contributions of the business community into strategically important actions.

\section{References}

1. N. Vatin, D. Nemova, D. Nabiullina, A. Ovdienko, Applied Mechanics and Materials, 725-726, 1434-1444 (2015)

2. T.K. Giap, W.W. Thye, G.A Aw. World Review of Science, Technology and Sustainable Development, 2(11), 176-196 (2014)

3. Information on http://spbhram.ru/2013/ecology/nehr/4698

4. Information on http://gumilevica.kulichki.net/EBE/ebe04.htm\#ebe04chapter14yu 
5. D. Meadows, J. Randers, D. Meadows. Limits to Growth: The 30-Year Update (Chelsea Green Publishing, 2004)

6. Information on: http://vernadsky.lib.ru/e texts/archive/Vernadsky_V.I._Avtotrofnost_ Chelovechestva.html

7. V.A. Ilyichev. Biosfernaya sovmestimost': Tekhnologii vnedreniya innovatsiy. Goroda, razvivayushchie cheloveka (Librokom, Moscow, 2011)

8. V.A. Ilyichev, V.I. Kolchunov, S. G. Emelyanov, N. V. Bakaeva, Applied Mechanics and Materials, 725-726, 1224-1230 (2015)

9. D. V. Danilevich, N. V. Bakayeva, I.V. Shishkina, Biosfernaya sovmestimost': chelovek, region, tekhnologii, 2(10), 88-100 (2015)

10. V.A. Ilyichev, A.M. Karimov, V.I. Kolchunov, V.V. Aleksashina, N.V. Bakaeva, S.A. Kobeleva, Zhilishchnoe stroitel'stvo, 1, 2-10 (2012)

11. K.K. Kolin, Strategicheskie prioritety, 1, 6-31 (2014)

12. A.D. Ursul, Strategicheskie prioritety, 1, 31-41 (2014)

13. I.K. Liseev. Materialy Mezhdunarodnoy nauchno-prakticheskoy konferentsii. 12-13 marta 2014g. BGITA, Bryansk, 306-311 (2012)

14. I.P. Pryadko, K.V. Orlina, Kazanskaya nauka, 6, 245-248 (2014)

15. S.N. Rumyantsev, A. L. Bachurin, Trudy 6-y Mezhdunarodnoy nauchno-prakticheskoy konferentsii "Innovatsionnye tekhnologicheskie resheniya dlya ekologicheski ustoychivogo stroitel'stva i gorodskogo kommunal'nogo khozyaystva". MGSU, Moskva, 127-135 (2014)

16. Z.I. Ivanova. Etnomental'nye, etnoreligioznye osnovy sozdaniya biosferosovmestimykh gorodov i poseleniy. Materialy Mezhdunarodnoy nauchnoprakticheskoy konferentsii «Biosfernosovmestimye goroda i poseleniya» 11-13 dekabrya 2012g. BGITA, Bryansk, 23-29 (2012)

17. A.D. Ishkov, N.G. Miloradova. Ekonomika i predprinimatel'stvo, 9, 884-887 (2014)

18. V.A. Ilyichev.. Strategicheskie prioritety, 1, 42-58 (2014)

19. Information on http://spkurdyumov.narod.ru/Stepin11.htm

20. O. Gamayunova, N. Vatin. Applied Mechanics and Materials, 725-726, 1493-1498 (2015)

21. N.G. Miloradova, A.D. Ishkov. Psikhologiya upravlencheskoy deyatel'nosti: izmenenie podkhodov (MGSU, Moscow, 2014)

22. N.G. Miloradova, Psikhologicheskie problemy zhiteley bol'shikh Trudy pyatoy Vserossiyskoy i tret'yey Mezhdunarodnoy nauchno-prakticheskoy konferentsii «Gumanitarnye problemy sovremennosti». 17-16 dekabrya 2008 goda. MGSU, Moskva, 99-100 (2008)

23. Information on http://www.archpeter.ru/arkhiv/2011/07/ekoustojjchivaja-arkhitektura/

24. Information on http://i-stp.ru/archive/5040

25. Z.A. Gaevskaya, S.D. Mityagin, Applied Mechanics and Materials, 587-589, 123-127 (2014)

26. S. Ershova, E. Smirnov, Applied Mechanics and Materials, 725-726, 1002-1006 (2015)

27. Information on http://www.consultant.ru/document/cons_doc_LAW_172910.

28. Information on http://www.consultant.ru/popular/okrsred.

29. A. Mickaityte, E.K. Zavadskas, A. Kaklauskas, L. Tupenaite. International Journal of Strategic Property Management, 12, 53-68 (2008)

30. L. Tupenaite, E.K. Zavadskas, A. Kaklauskas, Z. Turskis, M. Seniut. Journal of Civil Engineering and Management, 16, 257-266 (2010)

31. A. Kaklauskas, E.K. Zavadskas, D. Bardauskienè, R. Dargis, The harmonious development of real estate: a monograph (Technika Publ., Vilnius, 2014)

32. N. Banaytiene, A. Banaytis, A. Kaklauskas, E.K. Zavadskas. Omega - International Journal for Management Science, 36(3), 429-441 (2008) 